\title{
Chromium (VI) sorption on quaternized rice hulls
}

\begin{abstract}
The sorption of $\mathrm{Cr}(\mathrm{VI})$ from synthetic solution and electroplating waste by quaternized rice hulls was investigated under laboratory conditions to assess its potential in removing $\mathrm{Cr}(\mathrm{VI})$. The results show that quaternized rice hulls provided higher sorption capacity and a more workable $\mathrm{pH}$ range as compared to the untreated rice hulls. From the Langmuir isotherm the maximum sorption capacity of $\mathrm{Cr}(\mathrm{VI})$ was $32.3 \mathrm{mg} / \mathrm{g}$ at $\mathrm{pH} 4.82$ at $25^{\circ} \mathrm{C}$. Column studies showed that $\mathrm{Cr}(\mathrm{VI})$ and $\mathrm{Cu}(1 \mathrm{l})$ from electroplating waste could be successfully removed or reduced using a combination of untreated and quaternized rice hulls. The effect of different anions on the sorption capacity of quarternized rice hulls was discussed.
\end{abstract}

Keyword: Electroplating waste; Hexavalent chromium; Quaternized rice hulls; Sorption 